\title{
Possibility of expanding the protective effect of immunization and facilitating the assent to vaccination
}

\author{
Lehetőség az immunizálás védőhatásának növelésére és az oltás elfogadásának \\ motiválására
}

Author: $\quad$ Nagy Van Asschené Adrienne Zsófia $\triangle$

Budapest Föváros 2. Kerületi Egészségügyi Szolgálata

Submitted: 2019.12. 05.

doi: $\quad$ 10.24365/ef.v61i1.544

\begin{abstract}
Summary:
Introduction: In Hungary vaccination against Hepatitis B is mandatory in 7th grade (age 12-13) and is given by the school doctor. In this pilot study, following the best practices for patient-centered communication, a program was organized when the school doctor met the classes prior to immunization for an interactive conversation. The aim of the program was to minimize the possible fears of the students about vaccination, to seek their assent to immunization, to get the adolescents involved in disease prevention, and to expand the protective effect of immunization by means of health education. Indirect aims were to facilitate responsible health behaviour and to improve vaccine adherence in the future. In association with the immunization against Hepatitis $B$, the program was focused on protecting the liver and health generally. With the active participation of the students and a natural flow of questions several issues of health protection were reached.

Method: To evaluate the success of the program described in the article, a questionnaire was used.

Results: Participation on the evaluation 8, 20 and 32 months after the program was 85\%, $65 \%$ and $30 \%$ respectively, showing that it has reached the attention of the adolescents. On the question how the program influenced their attitude towards immunization, 63\% of the answers indicated positive effect, 33\% negated any change in attitude and $4 \%$ had remaining questions or was still stressed about the immunization.

Conclusion: At the mandatory vaccination of 7 th graders against hepatitis $B$ by the school doctor, the school setting provides efficient circumstances for interactive communication; vaccination against hepatitis B provides a unique starting point for health education. The pilot study has demonstrated that the program was able to raise the adolescents' interest in topics of health protection with a lasting memory and that it could facilitate their assent to immunization. However, it has also proved that adolescents can be often stressed - and do have questions - about immunization and emphasises the need for programs to alleviate their stress and to answer their questions. It might be an important factor to prevent vaccine hesitancy and improve vaccine adherence in the future.
\end{abstract}

Keywords: health education; primary prevention; vaccine adherence; adolescent; school health care 


\section{Összefoglaló:}

Bevezetés: Magyarországon a Hepatitis B elleni védőoltást iskolai kötelező kampányoltás keretében 7. osztályos tanulóknak (12-13 éves kor) adják az iskolaorvosok. Ebben a próbakutatásban a páciens-központú kommunikáció legjobb gyakorlatát követve olyan programot szerveztünk, melyen az iskolaorvos az oltás előtt egy interaktív beszélgetésre találkozott az osztállyal. A program céljai voltak, hogy minimalizálja a tanulók lehetséges félelmét az oltással kapcsolatban, hogy megnyerje az ő tudatos beleegyezésüket az oltáshoz, hogy bevonja a fiatalokat a betegségmeglőzésbe, és hogy kiterjessze az immunizáció védő hatását az egészségnevelés módszere által. Indirekt célok voltak, hogy elősegítse a felelős egészség-magatartást és javítsa a jövőbeni oltás-elfogadást. A Hepatitis B oltáshoz kötődően a program fókusza a máj és általában az egészség védelme volt. A diákok aktív részvételével és a kérdések összefüggő láncolatával a program az egészségvédelem számos területét érintette.

Módszer: A cikkben leírt program eredményességének vizsgálatára kérdőíves felmérést használtam.

Eredmények: A kérdőíves felmérésben való részvétel 8, 20 és 32 hónappal a program után 85\%,65\% illetve 30\% volt, ami azt mutatja, hogy sikerült felkelteni a diákok figyelmét. Arra a kérdésre, hogy hogyan befolyásolta a program az oltáshoz való hozzáállásukat, a válaszok 63\%-ban pozitív hatást mutattak, 33\% tagadta, hogy változott volna a hozzáállása, 4\%-nak további kérdései maradtak, vagy így is stressznek élték meg az oltást.

Következtetések: A 7. osztályosok Hepatitis B elleni kampányoltása során az iskola hatékony környezetet teremt az iskolaorvossal való interaktív kommunikációra; a Hepatitis B elleni védőoltás egyedülálló kiindulópontot nyújt az egészségneveléshez.

A próbakutatás bebizonyította, hogy a program felkeltette a diákok érdeklődését az egészségmegőrzés témájával kapcsolatban maradandó emléket hagyva, és elősegítette a védőoltáshoz való tudatos beleegyezésüket. Azt is igazolta azonban, hogy a serdülők sokszor stresszként élik meg a védőoltást és kérdéseik vannak ezzel kapcsolatban. Nyomatékosítja továbbá olyan programok szükségességét, amelyek ezt a stresszt csökkentik, és a felmerülő kérdéseket megválaszolják. Utóbbi fontos tényező lehet a jövőbeni oltásellenesség megelőzésében és az oltási hajlandóság javításában.

Kulcsszavak: egészségnevelés; elsődleges megelőzés; oltási hajlandóság; serdülő; iskolaegészségügy

\section{INTRODUCTION}

In Hungary vaccination against Hepatitis $B$ is mandatory in 7th grade (age 12-13) and is given by the school doctor. Following best practices for patient-centered communication, in this pilot study the doctor met the classes prior to immunization for an interactive conversation. ${ }^{1}$ The aim was: (1) to

minimize the possible distress of the students about vaccination, (2) to seek their assent to immunization assuming their responsibility, (3) to get the adolescents involved in disease prevention, and
(4) to expand the protective effect of immunization by health education. ${ }^{2}$ Indirect aims were to facilitate responsible health behaviour and to prevent vaccine-hesitancy in the future.

\section{METHOD}

Time was set aside for $7^{\text {th }}$ grade classes to meet the school doctor for interactive communication prior to immunization against Hep B.

Key features of the program are:

- relaxed interactive communication in homeroom class; 
- linked to scheduled vaccination - therefore the information is serving students, not pushed upon them unreasonably;

- the point of view along the conversation is protecting the liver and health generally;

- not constrained to a narrow topic, rather put in a wider context;

- students might drive the conversation;

- by a natural flow of questions several issues of health protection could be reached;
- appreciating scientific and societal achievements puts individual efforts and sacrifices in a wider context

As outlined in Figure 1 immunization against Hepatitis B provides a great opportunity for health education.

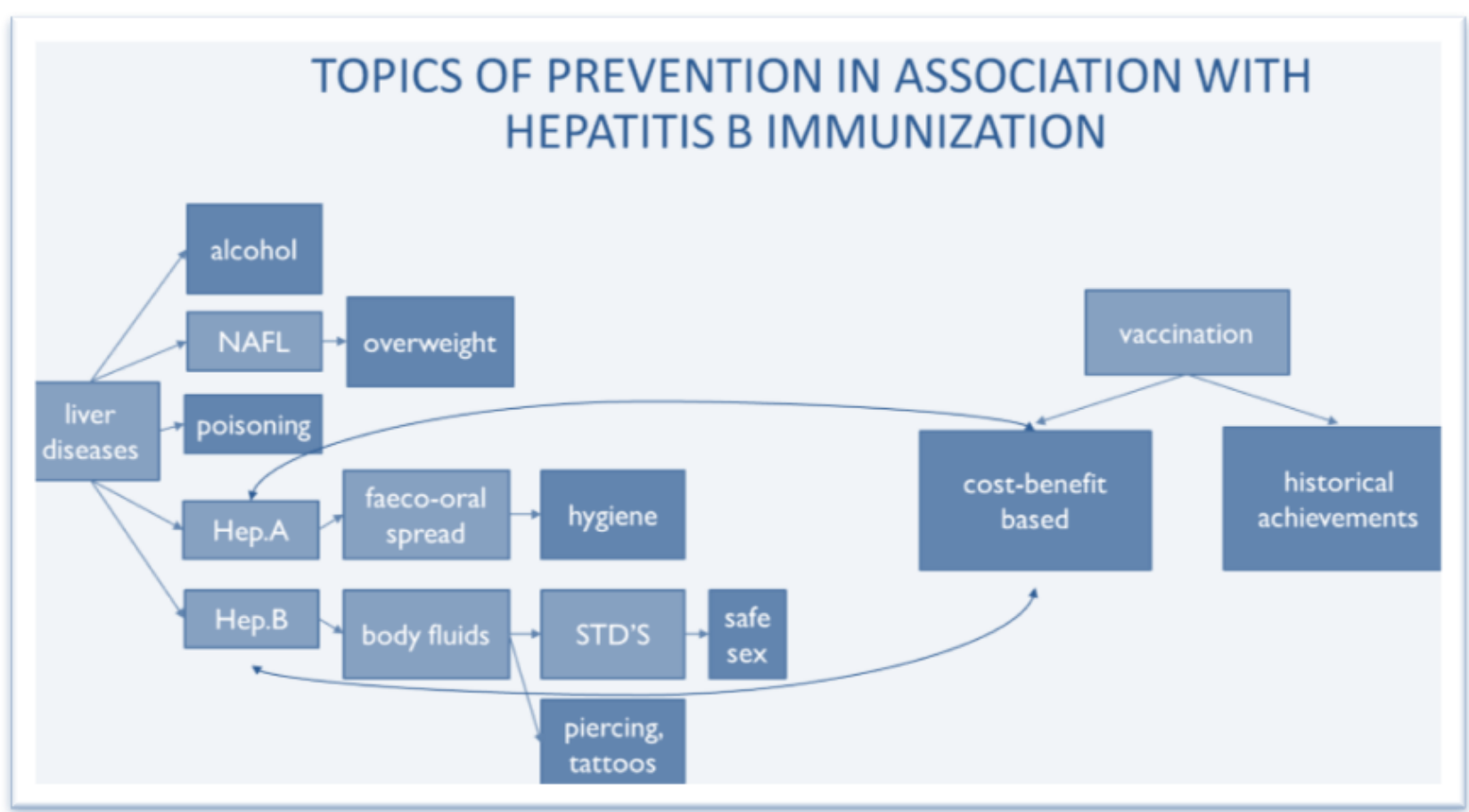

Source: own elaboration

\section{Detailed description of the program}

I meet the students in a homeroom class to inform them about the due vaccination. After calming their possible distress, I use this opportunity to talk with them. Hep B gives a unique starting point for health education considering that it affects the liver. To call the attention of the kids and make the conversation rewarding for them, I start asking questions, that they might be able to answer, such as

"What is the target organ of Hepatitis B?"; „Where is the liver?"; , "What does it do for us?"; ,"Can we live without it?" - we collect all the good answers.
Depending on interest or possible experience we might cover some of the symptoms of liver diseases at this stage, or progress to the next topic, namely „What else can harm this important organ?" Usually they answer "alcohol" - using an existent knowledge from earlier source. We might talk a bit about the risks and epidemiological significance of alcohol, and the possible toxic effect of blackmarket medications and poisons but need to go further to collect other possible harms. Mentioning the similarities of "non-alcoholic" fatty liver, brings the risk of significant overweight into our view. The next field of interest might be "What infections 
target the liver?" Some children might have had mononucleosis before, so we might touch on that, or someone might have received immunization against Hepatitis A for traveling. It is worth comparing the entrance route and the course of disease in case of Hepatitis A and Hep B. I tend to ask: „What might the reason be, that vaccination is mandatory against the $B$, while not against the A virus?". On one hand it takes us to see that vaccination is a costbenefit decision, and on the other hand calls attention on the importance of clean water and toilette hygiene in case of Hepatitis A. Focusing more on Hepatitis B we talk about the infectious risk of unprotected sex, and some other sexually transmitted diseases (STD). We appreciate that now the HPV vaccine can prevent cervical cancer. I am open all along to answer their questions as they arise, and to spend some more time on topics they are interested in, but I also gently guide the conversation to raise awareness of several issues of prevention. I find it important to appreciate the achievements of medicine in safer blood and organ donation since the screening for Hepatitis B, Hepatitis C and HIV are available. Nowadays as piercing and tattoos are considered cool amongst a lot of the youngsters, it is worth mentioning that needles used during those procedures should also be sterile. We do not finish the topic of liver diseases without pointing out, that one might suffer it due to unpreventable congenital, autoimmune - reasons, and sick people should never be blamed!

The conclusion however is quite clearly that it is certainly worth preventing what can be, and in this respect to get vaccinated against Hepatitis $B$ and HPV are good decisions.

Usually questions like whether the prick is painful, and some other concerns - had been answered already at the start, but as we get to the point of vaccination again, they might be ready to ask some more questions about it. The fact that the vaccine only contains recognisable particles, not the whole virus is important for them to know, as well the mechanism, how it only stimulates the defensive forces of their own body. Time allowing, we might talk a bit about the history of vaccination, but certainly appreciate the victory of eradicating smallpox, and making Europe free of polio.

Figure 1 described health education program has been ongoing for 5-6 years in certain schools of Budapest $2^{\text {nd }}$ district. In a few instances, due to practical issues, the program was held not at the optimal time (prior to the fist dose) but soon after the first dose of the two-dose vaccination series against Hepatitis $B$.

\section{EVALUATION}

To evaluate the effectivity of the program, I asked the students in four classes of $7^{\text {th }}$ graders, four classes of $8^{\text {th }}$ graders and two classes of $9^{\text {th }}$ graders to fill in a questionnaire about the program they had received in $7^{\text {th }}$ grade. The $7^{\text {th }}$ graders were asked 8 months after the program, the $8^{\text {th }}$ graders 20 months after it, the $9^{\text {th }}$ graders 32 months after it. The questionnaires were handed out by homeroom teachers accompanied by a letter asking anonym participation, they were collected also by the homeroom teachers.

The questionnaire consisted of nine questions; of those five were yes-or-no and multiple choice that did not require much effort; four questions were asking about factual knowledge in an elaborative way, but allowed quick yes or no answer as well (Do you know, against what... Do you remember ...). See Appendix for the full questionnaire.

The first question - "Have you participated in $7^{\text {th }}$ grade on a talk with me about the immunization? $\mathrm{Y} / \mathrm{N}^{\prime \prime}$ - was to rule out those who might have been absent on the day of the program, but it was also giving an easy way out for any student reluctant to spend more time on the questionnaire. This way participation in the questionnaire can be assumed voluntary, and already a sign of achieved attention. There were 205 appraisable questionnaires from a total of six classes. $85 \%$ of the 7 th graders ( 8 months after), $65 \%$ of the $8^{\text {th }}$ graders ( 20 months after), and $30 \%$ of the $9^{\text {th }}$ graders ( 32 months after) answered most of the questions. [Figure 2] 
Figure 2: Participation in questionnaire. Source: own elaboration

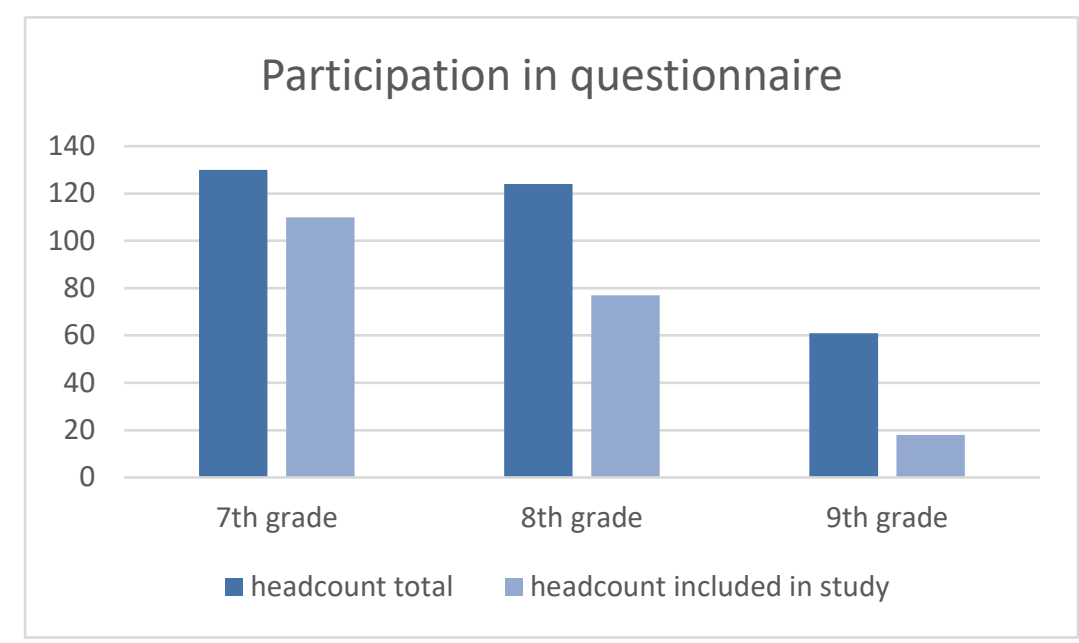

Source: own elaboration

On the question: "Do you remember the topics we talked about?" the "yes several things" answer was chosen by 28 of $1107^{\text {th }}$ graders, 7 of $768^{\text {th }}$ graders, and 1 of $189^{\text {th }}$ graders; the answer: "traces" was chosen by 61 of $1107^{\text {th }}$ graders, 34 of $768^{\text {th }}$ graders and 9 of $189^{\text {th }}$ graders; the "hardly at all" answer was chosen by 21 of $1107^{\text {th }}$ graders, 35 of $768^{\text {th }}$ graders and 8 of $189^{\text {th }}$ graders. [Figure 3-5]
On the question: „Did you find it interesting?" in $8^{\text {th }}$ and $9^{\text {th }}$ grade there was no significant difference between the numbers of yes and no answers, in $7^{\text {th }}$ grade more students answered "yes" on the question. [Figure 6-7]

Figure 3-5: Recall of the topics talked about

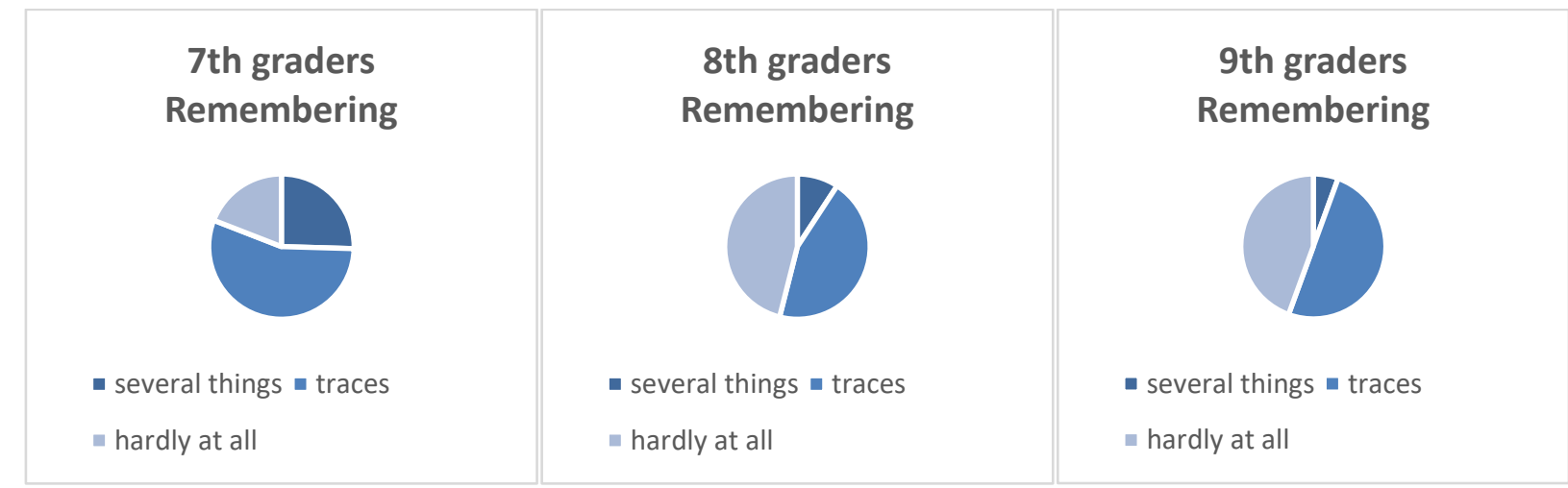

Source: own elaboration

On the question: „Have you received further information about health protection?", in $7^{\text {th }}$ and $8^{\text {th }}$ grade there was no significant difference between the numbers of yes and no answers, in $9^{\text {th }}$ grade more students answered "no" on this question. [Figure 6-7]
On the $4^{\text {th }}$ question: "Has the program influenced your attitude towards immunization?", 27\% chose the answer: "I got more consciously convinced of the benefit of vaccination" $22 \%$ chose: „it made me realise that vaccination is a good decision" $13 \%$ chose: „it reduced my distress", 4\% chose: „I had remaining questions, I was still stressed", and 33\% chose: "it has not influenced my view". [Figure 8-11] 
Figure 6-7: Degree of interest and acknowledgement of further information

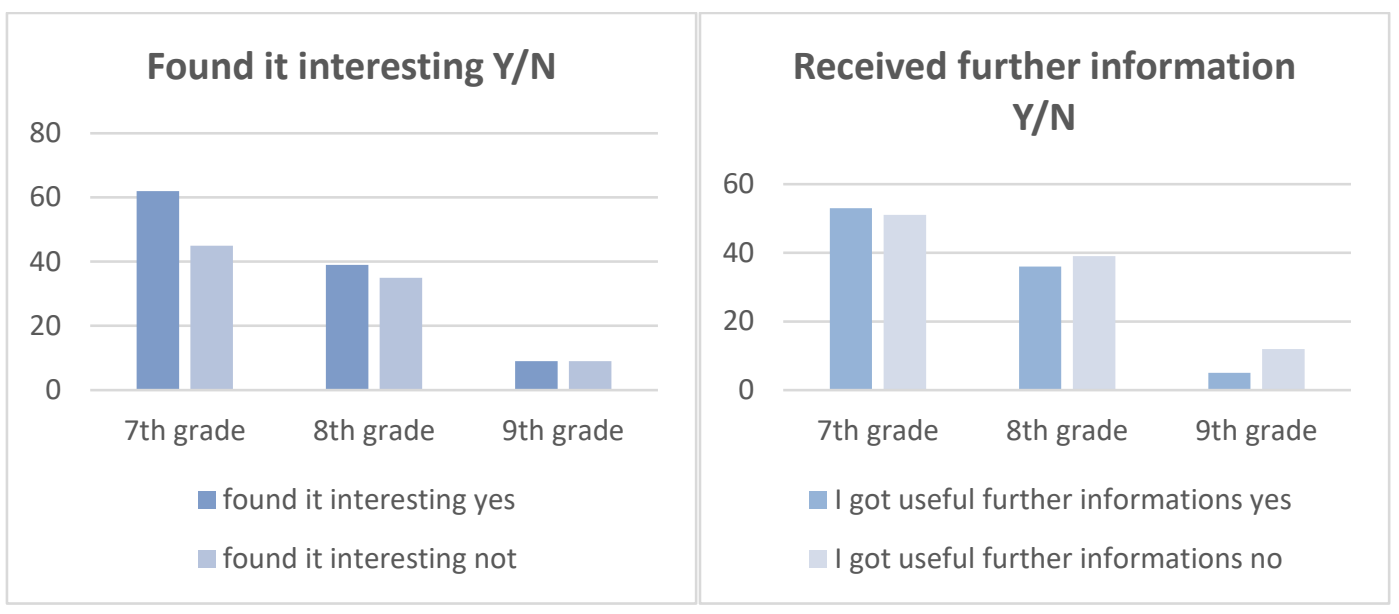

Source: own elaboration

Figure 8-11: Feedback on overall influence
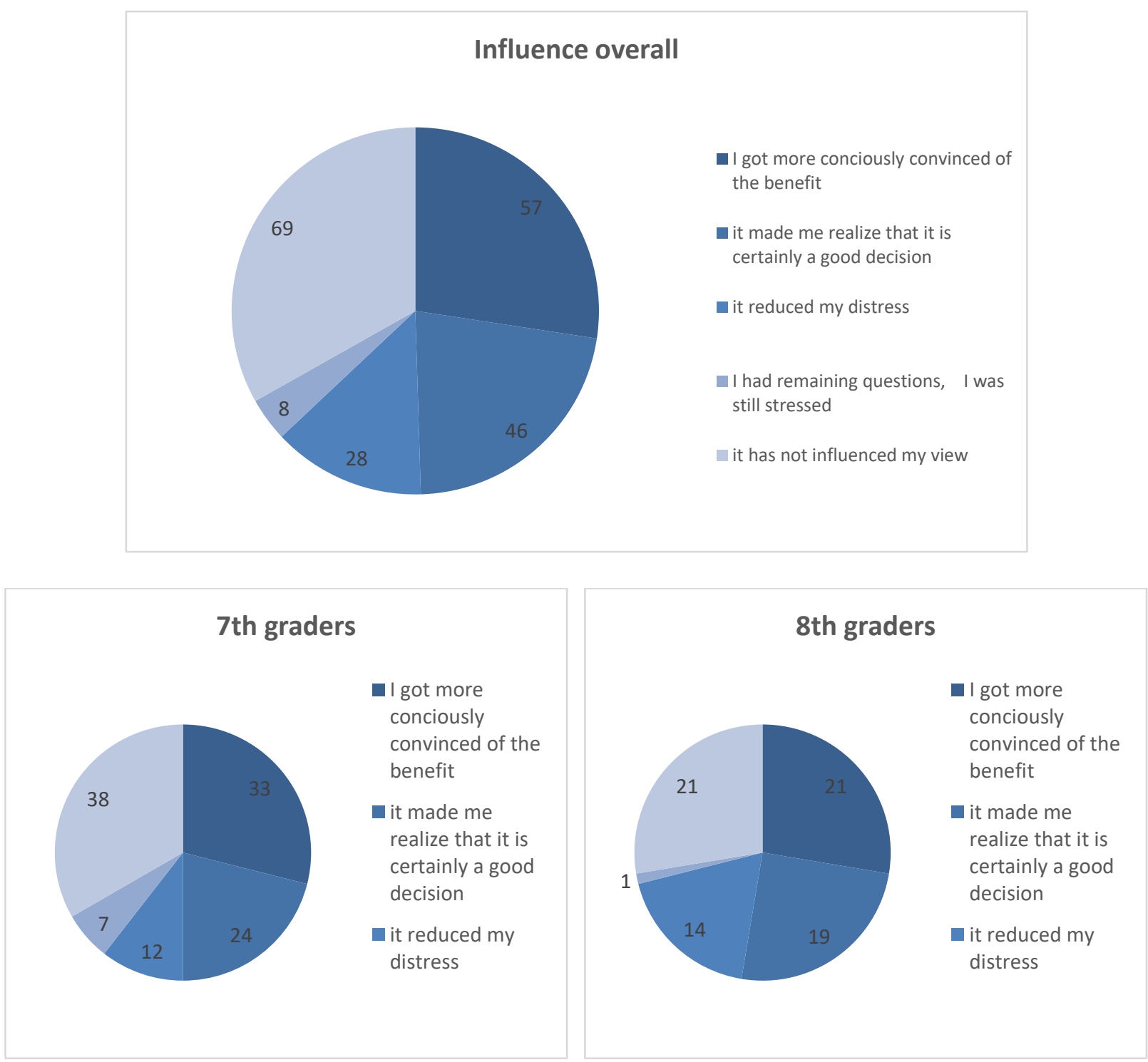


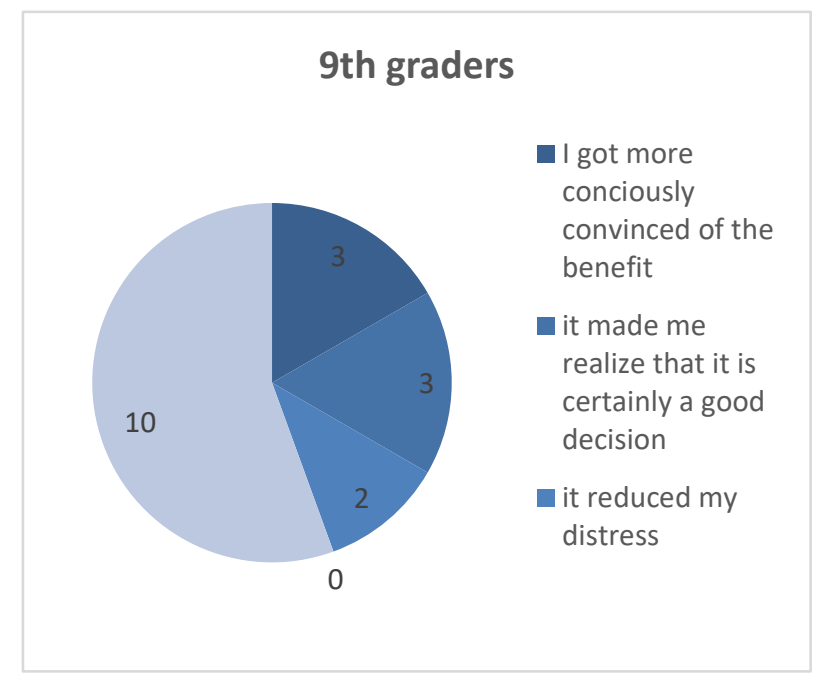

Source: own elaboration

Measuring factual knowledge was not a priority. 4 questions about factual knowledge could be answered in an elaborative way, but allowed quick yes or no answer as well ("Do you know, against what... Do you remember ..."). To evaluate these answers, I used a scoring method, where "yes" answer on minimum two questions gained 1 point maximum, correct factual answers earned one point each. Most of the students did not make the effort to elaborate on the answers, only written "yes" or "no" on "do you know ...? "do you remember? "questions. Exclusively "yes" answers gained only 1 point. The average score was best in $7^{\text {th }}$ grade - 2 points. [Figure 12]

Figure 12: Factual knowledge score

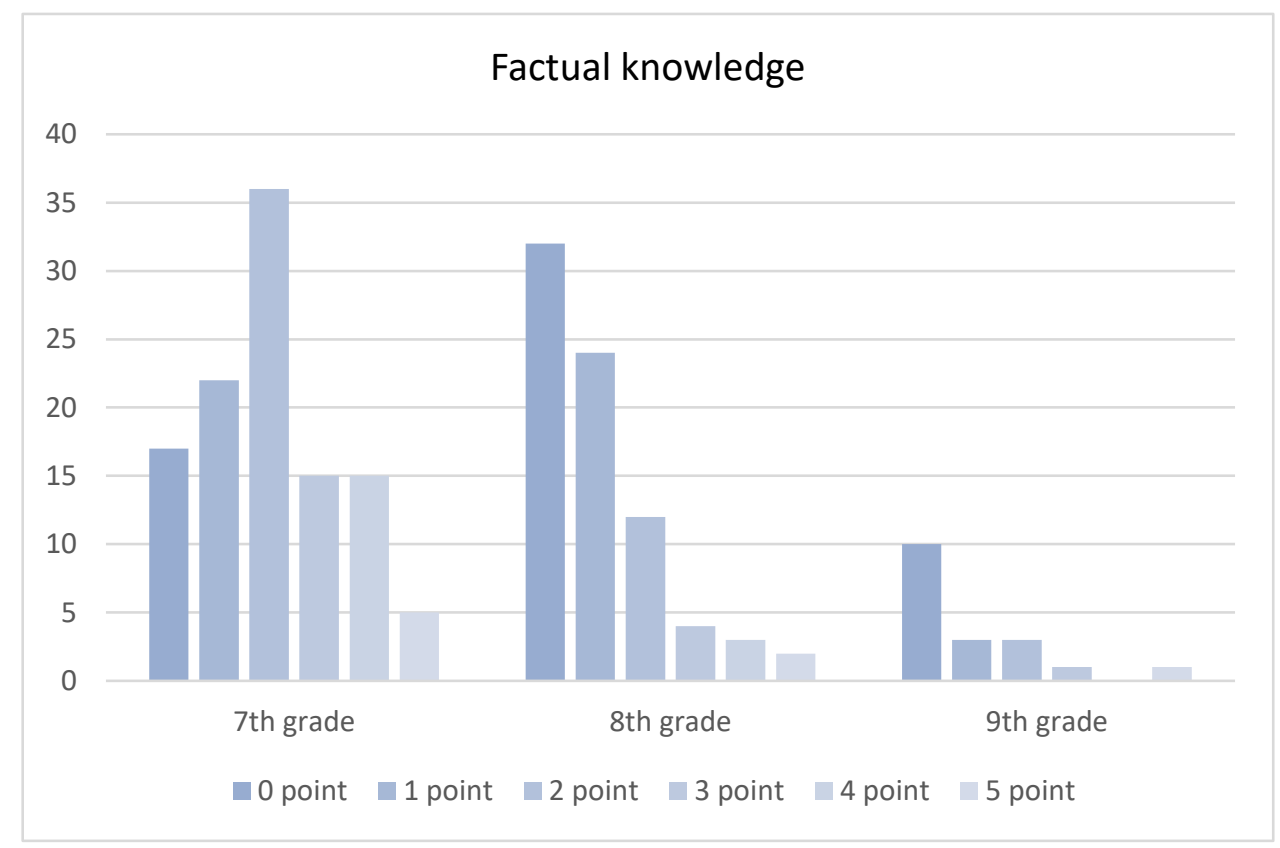

Source: own elaboration 


\section{DISCUSSION}

Voluntary participation on the evaluation of the program shows that it has reached the attention of the adolescents. $\ln 7^{\text {th }}$ grade 8 months after the program $85 \%$, in $8^{\text {th }}$ grade 20 months after the program $65 \%$, and in $9^{\text {th }}$ grade 32 months after the program 30\% filled in the questionnaire.

On the question: „Do you remember the topics we talked about?" one quarter of the $7^{\text {th }}$ graders (8 months later) answered "yes several things", and although the proportion decreased in $8^{\text {th }}$ and $9^{\text {th }}$ graders, one of the $9^{\text {th }}$ graders still felt to have strong memories about the program 32 months later. Overall most students responded to remember traces at least, although the proportion of those answering "hardly at all” has increased significantly in $8^{\text {th }}$ and $9^{\text {th }}$ grade.

Whether the program has influenced the students' attitude towards immunization, the biggest proportion, 33\% of the adolescents answered that it did not influence their view. They were clearly already convinced about its value before the program, in addition to the $27 \%$ who appreciated the program by answering: "I got more consciously convinced of the benefit of vaccination".

That $22 \%$ of the students who answered: „it made me realise that vaccination is a good decision" and the 13\% who chose: „it reduced my distress" illustrates the effectiveness of the program in increasing knowledge and buy-in for vaccination.

Sadly, there was still $4 \%$ who chose: "I had remaining questions I was still stressed". It could perhaps be explained by some cases of misfortunate logistics, when the program was not held before, but soon after the first vaccination of the $7^{\text {th }}$ graders. It also proves that adolescents can be stressed and do have questions about immunization and emphasises the need for programs to alleviate the stress and answer the questions.

The questions : „Did you find it interesting?" and "Have you received further information about health protection?" - have not gained significant difference between the number of "yes" and "no" answers apart from that on the question: „Did you find it interesting?" There were more "yes" than "no" answers in $7^{\text {th }}$ grade, and on the question "Have you received further information about health protection?" there were more "no" than "yes" answers in $9^{\text {th }}$ grade. Both features could be a sign of internalization of knowledge over time, however it is only hypothetical.

Evaluating factual knowledge was not a target. Answering questions concerning these, required more effort, and most students settled rather for an easy yes or no, therefore no valid conclusion can be drawn from these questions.

\section{CONCLUSIONS}

Following the criteria of patient-centred communication in the context of immunization of adolescents can have multiple beneficial effects. At the mandatory vaccination of $7^{\text {th }}$ graders against hepatitis B by the school doctor, the school setting provides efficient circumstances for interactive communication; vaccination against hepatitis $B$ provides a unique starting point for health education. Using the described method, several topics of disease prevention can be reached by a natural flow of questions, where sometimes the students can drive the conversation.

The pilot study has demonstrated that the program was able to raise the $7^{\text {th }}$ graders' interest in topics of health protection with a lasting memory and that it could facilitate the assent of students to immunization. It proves however that adolescents can be stressed and do have questions about immunization and emphasises the need for programs to alleviate their stress and answer their questions. It could also help to prevent parental vaccine hesitancy in the future.

Although indirect and long-term effects cannot be measured, results of the study provide ground to believe that the program had been effective to get the adolescents involved in disease prevention and to facilitate responsible health-behaviour. 


\section{APPENDIX}

Hello,

I'd like to ask you to fill in the questionnaire on the other side of this page. I'd like to know how useful it was for you to participate on our talk about the immunizations at the beginning of $7^{\text {th }}$ grade. Mostly you will have to circle one answer in a multiple choice, but at a few you could answer with your own words in case you remember, and that would be extra help for me. Write down also in case you have any further suggestions! You don't have to give your name but give your class please.

Thank you!

1. Have you participated in 7 th grade on a talk with me about the immunizations? $\mathrm{Y} / \mathrm{N}$

2. Did you find it interesting? $\mathrm{Y} / \mathrm{N}$

3. Do you remember the topics we talked about? a. yes several things b. traces c. hardly at all

4. Has the program influenced your attitude towards immunization?

a. I got more conciously convinced of the benefit of vaccination

b. it made me realise that vaccination is a good decision

c. it reduced my distress

d. I had remaining questions, I was still stressed

e. it has not influenced my view

5. Do you know, against what diseases you were immunized in 7 th grade?

6. Do you remember about which organ - the role and diseases of it - we were talking of?

7. What routes of infection were we talking about?

8. Do you know the mechanism of protection by immunization? Why is it needed for the vaccination to be repeated?

9. Have you received any further information about health-protection apart from those about the immunization? $\mathrm{Y} / \mathrm{N}$

\section{HIVATKOZÁSOK}

\footnotetext{
${ }^{1}$ King A, Hoppe RB. "Best practice" for patient-centered communication: a narrative review. J Grad Med Educ. 2013;5(3):385-393. doi: 10.4300/JGME-D-13-00072.1

${ }^{2}$ Considerations regarding consent in vaccinating children and adolescents between 6 and 17 years old https://www.who.int/immunization/programmes systems/policies strategies/consent note en.pdf?fbclid=lwAR1ygulzbP1BPTh8C3TeAsuL86IkaUFe-ywxAP3MD22mutiKbheZwO1IwbQ. Accessed 5 December 2019.
} 